\title{
Development Method of Village Consultative Body Post Head Village Election in Kalikayen Village, East Ungaran District
}

\author{
Mariyatul Qibtiyah¹, Siti Muafifah² \\ 1,2 Faculty of Law, Universitas Negeri Semarang, Indonesia \\ *Corresponding Author: M. Qibtiyah, email: qibtiya37@students.unnes.ac.id
}

Abstract: Various conditions after the Head Village Election have a great impact to the development of village itself especially on Village Constulative Body structure. The article highight some problems: (1) What is urgency of Village Council developing method, post Head of Village Election in Kalikayen?; and (2) What is the method of Village Council Development, Post Head of Village Election in Kalikayen? Therefore, there is a method of developing Village Council Post Village Election in order to answer the challenges mentioned above. The purpose of this program is to find out the guidance carried out by the regional government of the Village Council, the Village Council to be able to carry out their duties properly, and submit proposals to the government to pay more attention to the implementation of village government. After the completion of this dedication, the Village Council now understands their duties and functions as well as its role in village development. In addition, the Village Council already has the knowledge and experience in drafting village regulations. Outcomes of our service programs include the publication of a village guidebook module that contains the optimization of the implementation of the Village Law, the management of village funds, the techniques for establishing regulations in the Village. The next output is the draft village regulations and the village head regulations, as well as the activity proposal form and problem priority of each backwoods.

Keywords: Consultative Body; Development Method; Legal Services; Pilkades 


\section{A. Introduction}

The village has the authority to manage its own government, one of that is in determining the Head of Village, the community can directly elect the person who will become the Village Head through a democratic system by holding Village Head Elections. After the village head is elected, the village development planning process has begun to be compiled, including Village Deliberations, the preparation of the RPJMDes, RKPDes, APBDes, all of which is outlined in the Village Regulation. The Village Council has an important role in village development because it is a Government Organization that carries out legislative functions. In addition to this, the composition of the Village Consultative Council members is new and different from the previous year and many of them do not yet know the direction of the government system in the Village. Members of the Village Council come from different educational, environmental and economic backgrounds, so that they need guidance and assistance in carrying out their duties and functions as a Village Council.

Furthermore, one of the obstacles in village development planning after the election of the Village Head is the lack of understanding of the Village Council regarding its functions and the lack of knowledge and enthusiasm of the community regarding village development planning. If we look at the Village Authority as regulated in Law Number 6 of 2014 and Minister of Home Affairs Regulation No. 44 of 2016 concerning Village Authority, the Village has broad authority to administer the Village in order to achieve an independent and prosperous Village within the NKRI frame. In general, village authority encompasses authority in the area of administering village governance, implementing village development, fostering village community, and empowering village communities based on community initiatives, original rights and customs of the village. Seeing some of the problems mentioned above, we need a special coaching method so that the Village Council can carry out its duties for the next 6 years.

At this article, some of the formulation of the problems we will take is: (1) What is urgency of Village Council developing method, post Head of Village Election in Kalikayen?; and (2) What is the method of Village Council Development, Post Head of Village Election in Kalikayen?. This article is structured to find out the urgency of the formation of the Village Council after the Election of the Village Head and to describe the method of developing the Village Council for the Post Village Election of the Village Head in Kalikayen Village. 


\section{B. Method}

This research uses an empirical juridical approach. According to Waluyo, empirical legal research in other terms often reffered as sociological legal research and can also be referred to as field research. This sociological law research starts from primary data. Primary data or basic data is data obtained directly from the community as the first source through field research. Obtaining primary data from field research can be done either through observation, interviews or questionnaires. ${ }^{1}$

Our method is to do interviews and discussions with members of the Village Council and village officials. In addition we involve the community in this guidance process because the community has an important role in the duty of the Village Council. The location of this service was held in Kalikayen Village, Ungaran Timur District, Semarang Regency. The time of this dedication was carried out on July 15 to 27 August 2019. The activities that we carried out included holding an initial VILLAGE COUNCIL consultation, reviewing the Village Law, studying together to formulate village regulations, discussing preparations for the Musrenbang, planning the Musrenbang with community leaders.

The target of our development program is the Village Council, the village officials, the head of the $\mathrm{RT} / \mathrm{RW}$, the Institution in the Village. The focus of our coaching program is to understand the Village Law Together, the stages and techniques for establishing regulations in the Village, and to organize Village development through MUSRENBANG. We carried out this by dissecting the Village Law together with community leaders, assisting the Village Council in the process of forming Village Regulations, assisting each Village Chief in preparing the proposed activity and village consultation documents.

\section{Result and Discussion}

1. Analysis of Village Government on Village Autonomy

a. Village Autonomy

Since the enactment of Law No. 6 of 2014 concerning Villages, the Village now has its own authority to regulate the administration of its government and to develop Villages by maximizing potential through community participation and empowerment. This law is the result of community struggles that make villages the main concern of the government in realizing prosperity, justice and independence. The Village

Waluyo, Bambang. Penelitian Hukum Dalam Praktek. Jakarta: Sinar Grafika. 1996. p.16 
Law contains guidelines on village development that are realized through development planning deliberations, village financial management, village regulations, BUM Desa, village head elections, village consultative bodies. As a village, it should be proud and have the spirit to find the identity of the village so that it can become an independent and prosperous village in accordance with the ideals of the Indonesian people

Regional Autonomy in Indonesia has opened up as many opportunities as possible for regional governments to be responsible in managing their own government affairs. This is one of the answers to the problem of unbalanced development between the center and the regions as well as between districts and cities. This imbalance causes high rates of poverty in Indonesia. Based on BPS data (September, 2015) it states that the poverty rate in urban areas is $8.22 \%$ while the poverty rate in rural areas reaches $14.09 \% .^{2}$ Because of this, the government paid great attention to rural development, one of which was the birth of Law No. 6 of 2014 concerning Villages. This law gives broad authority to the village, including government governance, village development, empowerment, and fostering village communities.

Law No. 6 of 2014 concerning Villages provides broad space for the community to regulate development planning on the basis of community priority needs without being burdened by programs from various government agencies, here in after referred to as village autonomy. Village autonomy is genuine, round and complete autonomy and is not a gift from the government. Instead the government is obliged to respect the original autonomy held by the village. ${ }^{3}$

The village is a legal community unit that has the authority to manage and manage government affairs, the interests of the local community based on community initiatives, original rights, and / or traditional rights that are recognized and respected in the Republic of Indonesia's government system. ${ }^{4}$ The authority that has been given is the basis of the village to move to build the community in the village to become an independent and prosperous society. Even though the village has been granted special autonomy, this authority cannot be separated from the NKRI frame.

\footnotetext{
2 Nyimas, Latifah Letty Aziz. Otonomi Desa dan Efektivitas Dana Desa. Jurnal Penelitian Politik, Vol. 13.No. 2. 2016, p.193

3 HAW Widjaja, Otonomi Desa: Merupakan Otonomi yang Asli, Bulat dan Utuh, Jakarta, PT Raja Grafindo Persada, 2008, p.165.

4 M.Silahudin. Kewenangan Desa dan Regulasi Desa. Jakarta: Kementerian Desa, Pembangunan Daerah Tertinggal dan Transmigrasi Republik Indonesia. 2015, p.11
} 
Village autonomy is intended to make efforts to develop and improve village welfare more quickly, this will not happen if village development is still determined and centrally designed as in the past. The Village Authority contained in the Village Law states that villages have four authorities, including (1) authority based on original rights. This is different from previous legislation which states that existing government affairs are based on the village's original right, (2) local-scale village authority where the village has full authority to regulate and administer the village. In contrast to the previous legislation which states, governmental affairs which become the authority of the regency / city are handed over to village regulations, (3) authority assigned by the government, provincial government, or regency / city government. (4) Other authorities assigned by the Government, Provincial Regional Government, or Regency / City Regional Government in accordance with statutory provisions.

\section{b. Urgency of Village Government Assistance from Local Government}

The compilation of village regulations is very urgent especially after the birth of Law Number 6 of 2014 concerning Villages. ${ }^{5}$ The village must always make the Village Regulation as a legal protection for the village in implementing village programs for the welfare of the village. Therefore, each village must understand very well especially related to the compilation of Village Regulations. This is done so that the Village Regulations made by the Village Council and the Village Government can be in accordance with the provisions of existing laws and regulations and can run well in accordance with the provisions. ${ }^{6}$

To further strengthen understanding of Village Assistance, the Ministry of Villages issued Ministerial Regulation (Permen) No. 03 of 2015 concerning Village Facilitators. There it was explained that Village Facilitators were not managers of development projects in the village. Village Assistance Work is focused on efforts to empower village communities through the social learning process. Thus, village assistance is not burdened with the dutys of managing financial administration and village development based on the Village Law which has become the duty and responsibility of the village government. ${ }^{7}$

The aim of Village Assistance is to increase the capacity, effectiveness and accountability of village governments and village development. Increase

Undang-Undang Republik Indonesia Nomor 6 Tahun 2014 tentang Desa.

Djogo, Tony.(2003). Kelembagaan dan Kebijakan Dalam Pengembangan Agroforesti. Word Agroforestry Centre (ICRAF) Southeast Asia.

Sumber Saparin, Luas Bidang Kegiatan Pemerintahan, Tata Pemerintahan Dan Administrasi Pemerintahan Desa, Ghalia Indonesia. p 15 
initiatives, awareness and participation of village communities in participatory village development. Improve the synergy of inter-sectoral Village development programs and optimize the village's local assets emancipatively. Within the scope of assistance the village community is implemented in stages to empower and strengthen the village. Village community facilitation is in accordance with the needs based on the geographical conditions of the region, the value of the Village APB, and the scope of activities that are assisted by the Government, provincial government, district / city government, and Village Government to make efforts to empower village communities through sustainable village community assistance, including in terms of providing human resources.

Article 127 of Government Regulation No. 43 of 2014 provides more detailed directions. Village facilitators must oversee the planning and budgeting in favor of the interests of the poor, the disabled, women, children and marginal groups. If PNPM facilitators only focus on BLM budgeting only, then village facilitators must oversee village financial consolidation through the APBDesa. Village income sources, starting from PADesa, ADD from the APBN, Village Fund Allocation (ADD) from the APBD, revenue sharing from taxes and levies, and various other sources of income must be managed transparently and accountably through the APBDesa.

The administration of village government still faces a number of challenges and obstacles. a number of obstacles faced in the current administration of village governance include the low effectiveness of institutional and village governance and community services. In addition, the low capacity and quality of service of village government apparatus, the limited access of the community to village administration information, and the weak coordination between Ministries / Institutions and regional governments in village development.

Law Number 6 of 2014 concerning villages mandates that the Government, Provincial Regional Government, and Regency Regional Government to empower the village community. Empowerment of rural communities is carried out among others by village assistance. Article 112 paragraph (4) of Law No. 6/2014 concerning Villages mandates that the empowerment of Village communities is carried out with assistance in planning, implementing, and monitoring Village and rural area development.

In the framework of implementing the Village Law, technically it is carried out by district / city regional work units, which up to now have been assisted by district experts (TA), village assistance staff (PD), village location assistance (PLD), village community empowerment cadres, and 
third party. Whereas the duty of the sub-district head as subordinate regent I mayor is to coordinate and facilitate village facilitation in the region. The sub-district has a very strategic function in the framework of implementing the Village Law. But what happens in the field, the implementation of village assistance so far is still running separately. So that the village assistance process does not run optimally. "Sectoral ego is still very thick".

On the other hand, new mentality in treating the the village has not fully inspired the heart and thoughts of our majority. "Both the government and outside the government".

The existing conditions in Kalikayen Village, many Village Council members only graduated from high school and a number of Strata 1 graduates, but the scientific field they owned did not support the governmental administration function. Besides this, the regeneration system has not yet been formed. This has an impact on the death of learning both from the evaluation or criticism of suggestions from the previous government related to the implementation of the dutys and functions of the Village Council.

On the other hand, coaching activities are activities that are futures in nature and not in a short time such as a discussion or seminar model. The coaching method is oriented towards the learning process to reach an understanding and realize the importance of the role of the Village Council for development in the Kalikayen Village. Only a few Village Councils know the direction of their goals going forward, so they need to be directed. One thing that needs to be considered in village development is the alignment between the provincial development plan with the Regency / City and Regency / City and District and / or Village. The harmony is aimed at making the development effective and vertically harmonizing the laws and regulations.

Village Council members are representatives of the villagers concerned who are determined by deliberation and consensus. Village Council leaders are elected from and by Village Council members. The term of office of Village Council members is 6 (six) years and can be elected again for 1 (one) next term of office. The terms and procedures for determining Village Council members and leaders are regulated in Regional Regulations that are guided by Government Regulations. The number of members of the Village Representative Body is determined based on the number of villagers concerned with the following conditions: (1) The number of villagers up to 1,500 inhabitants, the number of Village Council members is 5 (five) people. (2) The number of villagers is between 1,501 to 2,000 people, the number of Village Council members is 7 (seven) people. (3) The number of villagers is 
between 2,001 and 2,500, and there are 9 (nine) Village Council members. (4) The number of villagers is between 2,501 and 3,000 people, with a total of 11 (eleven) Village Council members. (5) The population of more than 3,000 people, the number of Village Council members is 13 (thirteen) people. ${ }^{8}$

The description of the dynamics of structuring and strengthening the village government institutions behind the scheme offered by the Village Law shows that village development in the economic field is better than development in the village institutional field after the Village Law. That is, the openness of space owned by the village government then prioritizes economic development. Of course, this is not appropriate because economic development and political development must be aligned together. Although, in certain degrees and periods there is a tendency for implementation to slightly highlight one of the dimensions that are needed, but village development should not prioritize one aspect of the two things dominantly .

\section{c. The Role of the Provincial Government in Village Development and Supervision}

As stipulated in the Village Law Article 114, the Provincial Government has the role of supervision and guidance for the village, some of the roles of the provincial government can be described as follows 9 :

a. Conduct training for districts / cities in the context of preparation

b. Regency / City Regional Regulations governing villages;

c. Conduct development of districts / cities in the context of granting Village Fund Allocation;

d. Conduct training to improve the capacity of village heads and village officials, the Village Council, and community organizations;

e. Fostering village government management;

f. Fostering efforts to accelerate village development through financial assistance, assistance, and technical assistance;

g. Conducting technical guidance in certain fields that is not possible by the district / city government;

h. Inventory of provincial authorities carried out by villages;

i. Carries out and supervises the determination of the regency / city Regional Budget in village financing;

j. Conduct training for regencies / cities in the framework of village area management;

8 Miskawati dan Heri Tahir. Perana Badan Permusyawaratan Desa (BPD) dalam Pembangunan Desa (Studi di Desa Tolajuk Kecamatan Latimojong Kabupaten Luwu). Makassar: Universitas Negeri Makassar. 2014. pp-41-42

$9 \quad$ Moch Musoffa Ihsan.2015. Ketahanan Masyarakat Desa. Kementrian Desa. Jakarta: Pembangunan Daerah Teringgal, Dan Transmigrasi Republik Indonesia, p 32. 
k. Assist the government in the determination of the unity of customary law communities as villages;

1. Fostering and overseeing the establishment of regency / city BUM Desa and inter-village cooperation institutions.

$\mathrm{m}$. And others in accordance with local regulations

In relation to village financial management, the provincial government can allocate financial assistance to villages in the provincial budget which is one of the sources of village income that will be set forth in the village budget.

The village perspective is different from the government perspective, which sees the village as part of the government, or sees that the center, province, district / city, district and village / kelurahan are hierarchical structures in the Republic of Indonesia government. The government works under the control of the President which flows hierarchically and top down from top to village level. From a government perspective, the village is the smallest, lowest, front and closest government organization. Most "small" means that the area and the dutys of government carried by the village have the smallest scope or size compared to district / city, provincial and central government organizations. Most "bottom" means the village occupies the composition or the lowest layer of government in the governance of the Unitary Republic of Indonesia (NKRI). But "bottom" does not mean that the village is subordinate to the district / city, or the village head is not subordinate to the regent / mayor. The village is not domiciled as a government within the district / city government system as affirmed in Article 200 of Law Number 32 Year 2004. According to Law Number 6 of 2014 , the village is domiciled in the district/city. This is congruent with the existence of districts/cities in the province.

Bottom also means that the village is a government organization that is directly related and integrated with the social, cultural and economic life of everyday people. The term "bottom" also has similarities to the terms "front" and "close". The term "front" means that the village is related directly with citizens in the fields of government, service, development, empowerment and society. Most Indonesians come to the village government every time they will get services or solve various social problems. Therefore the government and the village officials, which is different from the government and the regional apparatus, must be prepared to work serving the community for as long 24 hours non-stop, do not know leave and vacation. Whereas the term "close" means that administratively and geographically, the village government and community members are easy to reach and connect with. Socially, "close" means that 
the village blends with the pulse of the daily socio-cultural life of the local community.

The two perspectives intersect and intersect. But according to constitutional, historical and sociological considerations, the portion of the village as a self governing community is far greater and stronger than the portion of the village as a local self government. Remember that Law Number 6 of 2014 is the Village Law, not the Law on Village Government. Village as a self governing community is very different from formal government, general government or regional government in terms of village authority, structure and apparatus, and village governance. ${ }^{10}$

In accordance with the principles of recognition and subsidiarity, villages have authority based on the origin rights and local scale authority of the village, which is certainly very different from the authority of the regional government. In terms of governance, the village has a village meeting, as a collective forum between the village government, the Village Council, community organizations, traditional institutions and broad community components, to agree on strategic matters relating to the livelihoods of the village. All this illustrates that the character of the village as a self governing community is much bigger and stronger.

Adjustment of the implementation of the village government to the Village Law policy, there is a structuring and strengthening of the village government by giving recognition in respect of the existence of the village and the village community within the framework of a unitary state. This then gave the village government in the framework of a unitary state. This then gave the village government and village people more flexibility in managing the village. Furthermore, from the presentation of the implementation of the village law in the economic field, it is seen that the achievement of better development. It's just that the synergy and coordination functions at the central government need to be improved. Furthermore, it is related to political development, especially related to village governance, as has been explained that there is stuttering and also fear of the use of authority and a large budget. This is still a work in the village assistance program.

\section{d. Election of Village Head in Kalikayen}

Village head election is the exercise of people's sovereignty in the village in order to elect village heads who are direct, public, free, secret, honest and fair. Election of Village Heads in Kalikayen Village is held simultaneously with other Villages in Semarang Regency in 2018. The

10 Ndraha, Taliziduhu. 2002. Pembangunan Masyarakat. Jakarta, Rineka Cipta, p.22 
village head is a village government official who has the authority, duties and obligations to organize his village household and carry out the duties of the government and local government. Village head election activities are carried out by the pilkades committee formed by the Village Council to organize the village head election process.

Upon the implementation of this village head election, the community hopes that elected leaders who are fair, wise and have a clear vision going forward. The election of the new village head also ended the term of office of the village government in the previous period which will then be composed of the new village government organization structure through a selection process regulated in the legislation.

The election of village heads is carried out through several stages, including the stages of preparation, nomination, voting and determination. The Village Council forms a simultaneous election for village heads and an inter-village head election committee. The formation of the committee was determined by a Village Council decision consisting of village officials and community elements. The number of committee members is adjusted to the duty load and financial capacity. The committee is responsible to the Village Council. In the event that committee members do not carry out their duties and obligations, they can be dismissed with a Village Council decision. The committee conducts a selection and selection of prospective Village Heads from time to time. Screening of prospective Village Head candidates to become Village Head candidates, at least 2 (two) people and at most 3 (three) people. If the number of prospective candidates who meet the requirements is more than 3 (three), the committee makes additional selections using the criteria of having knowledge of Village Government, education level, age and other requirements set by the Regent / Mayor. If prospective candidates meet the requirements of less than 2 (two) people, the committee extends the registration time for 7 (seven) days. If the prospective candidate who meets the requirements remains less than 2 (two) after the extension of the registration period, the Village Council postpones the election of the Village Head until the time determined later. ${ }^{11}$

11 Tim Kementerian Dalam Negeri dan Australian Government. Buku Panduan BPD 2018. Jakarta, KOMPAK Kemitraan Pemerintah Australia dan Indonesia, pp.29-30 


\section{Implementation of Legal \& Community Services on Kalikayen Village}

a. Assistance in the Formation of Village Regulations

Designers of Village Regulations need to make Village Regulations on behalf of and for the benefit of the community. ${ }^{12}$ The first step that must be taken is to ask questions about the types of problems faced by the community. Problems can include many things, including the degradation and deviation of resources which results in social unrest and inequality. In addition to identifying the problem, the draft designer must also identify the cause of the problem (root of the problem) and the parties affected by the various types of problems. To identify problems, there are several theories that can be used to identify, for example, the ROCCIPI method (Rule, Opportunity, Capacity, Communications, Interest, Process, and Ideology).

Rule (Regulations), which may be identified are: wording of rules is unclear or ambiguous, regulations may provide opportunities for problem behavior, do not deal with the causes of problematic behavior, provide opportunities for implementation that are not transparent, irresponsible, and not participatory, and provide unnecessary authority to implementing officials in deciding what and how to change problematic behavior.

Opportunity, to identify whether the environment around the intended party of a Village Regulations allows them to behave as instructed by the Village Regulations or not? And does this environment make suitable behavior impossible?

Capacity (ability), to identify whether the actors have the ability to behave as determined by existing regulations, In practice, opportunities and willingness to overlap. It does not matter which ROCCIPI category inspires a drafter of the RanVillage Regulations when formulating explanatory hypotheses. These categories succeed in stimulating draft draftsmen to identify the causes of problematic behavior that their designs must change.

Communications, the ignorance of a role behavior about Village Regulations may explain why he behaves inappropriately. Whether the authorities have taken adequate steps to communicate the existing regulations to the intended parties.

Interest, whether there are material or non-material (social) interests that affect the role holder in acting according to or not with existing rules.

Process, according to the criteria and procedures whether the process by which the role actors decide to comply with the Village Regulations or not. Usually, if a group of role actors consists of individuals, the process

12 Marjoko, Saputra Iswan dan Hasibuan Hawari. 2013. Pemerintah Desa yang Baik. Medan, Bitra Indonesia, The Activator For Rural Progress, p.112 
category produces several hypotheses that are useful for explaining their behavior. People usually decide for themselves whether to obey the rules or not.

Ideology, whether the values, habits and customs that exist enough to influence the role holder to act according to or contrary to existing rules. ${ }^{13}$

In the preparation of the Village Regulations so far, it is still not equipped with academic studies. In order for the Village Regulations to be prepared to truly answer the needs of the village community and answer the problems to be arranged, the arrangement of academic studies becomes very important. Substantially, academic studies must examine three substance problems, namely: (1) Answering the question of why a new Village Regulations is needed, (2) the scope of material content and the main components of the Village Regulations, (3) the process that will be used to prepare and authorize Village Regulations.

In general the steps in the process of drafting new village regulations are as follows:

(1) Step 1: Identify the Problem

(2) Step 2: Identify the Legal baseline, and how new village regulations can solve the problem.

(3) Step 3: Preparation of academic studies

(4) Step 4: procedures for preparing Village Regulations: (a) the process of preparing RanVillage Regulations in Village Council and (b) the process of preparing Draft Village Regulation in the village government, (c) the process of obtaining Village Council approval, (f) the process of ratification and stipulation as village sheets.

(5) Step 5: Village Regulations oversight mechanism

13 Hendry Maddick \& Hanif Nurcholis, 2007, Teori dan Praktik Pemerintahan dan Otonomi Daerah,Grasindo, Jakarta. p. 7 


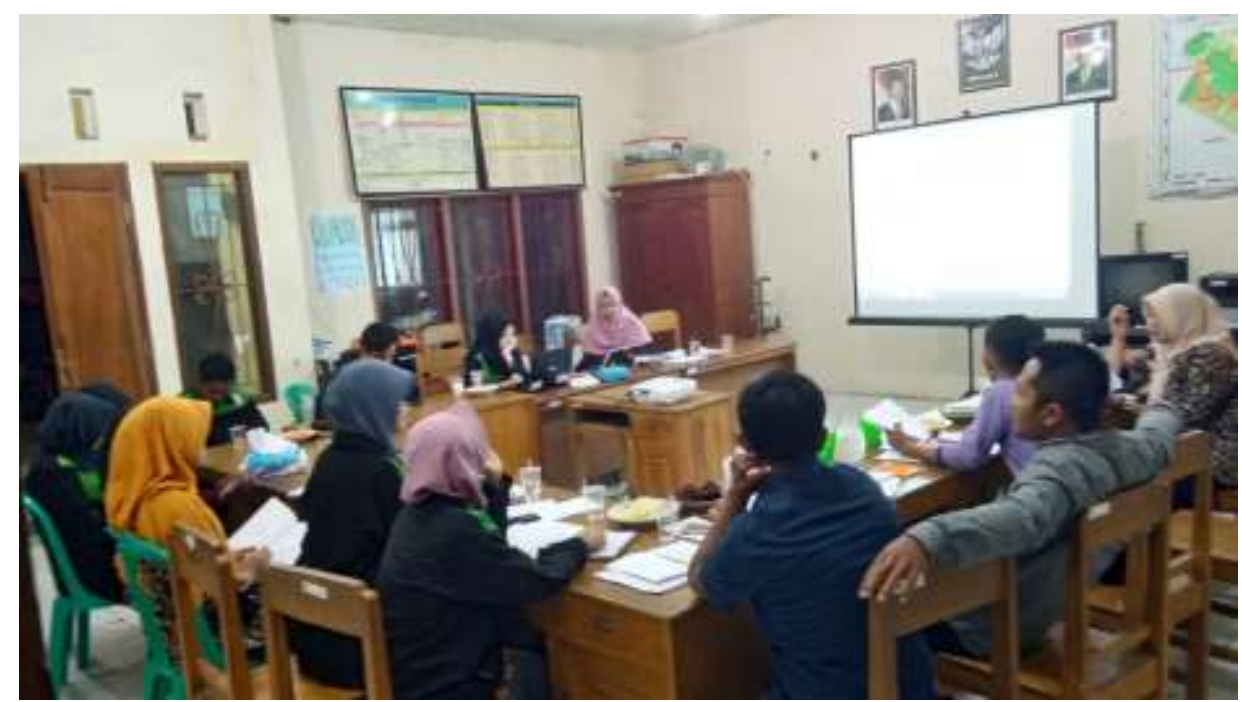

Figure 1. Mentoring Establishment of Village Regulations. Source: Authors' personal document date; July 25, 2019

\section{b. Development Planning Consultation Assistance}

The village has the authority and right to regulate its territory in accordance with the aspirations of the people who live in the village area concerned. This authority will determine the position and role of Musrenbang towards development in the village because it sees the importance of Musrenbang in promoting village autonomy. The village musrenbang should not be narrowed down to routine activities, only to fill out a list of proposed activities that will be taken to the sub-district, but the direction of the policy is truly part of the implementation of village autonomy.

Village development planning covers the areas of village governance, implementation of village development, village community development and village community empowerment. Village development planning is arranged in a long term including (1) a medium-term development plan for a period of six years, and (2) an annual village development plan which is often called a village government work plan abbreviated as RKPDes is a translation of the Village RPJM for a period of 1 (one) year . ${ }^{14}$

The village medium term development plan contains at least the vision and mission of the village head, the direction of the village development policy, and the plan of activities covering the fields of village governance, the implementation of village development and village community empowerment, the preparation of the village medium term development plan is carried out taking into account the objective conditions of the village and the priority of the district's programs / activities City. In

14 Peraturan Menteri Dalam Negeri Nomor 114 Tahun 2014 tentang Pedoman Pembangunan Desa 
the preparation of the Village RPJM carried out by activities (1) the formation of the Village RPJM drafting team, (2) alignment of district / city development planning policies, (3) assessment of village conditions, (4) preparation of village development plans through village deliberations, (5) preparation the village medium term development plan, (6) preparation of village development plans through village development planning meetings; and (7) determination of the Village RPJM.

The village RPJM drafting team consists of the village head as the coach, the village secretary as the chair, the head of the community empowerment agency as the secretary and members from the village officials, the community empowerment agency, the village community empowerment cadre and other elements of the community. The drafting team all numbered at least 7 people and at most 11 people. As law students who incidentally have learned about regional autonomy, it is useful for us to be able to convey and assist the community in the development planning process. ${ }^{15}$ The things we do in assisting include:

1) Telling the community about the substance contained in Law No. 6 of 2014 concerning Villages, specifically the role of the community in development planning as outlined in the form of a special article MUSRENBANG Desa

2) Accompanying each stage of the village MUSRENBANG

1. Village Pre-Musrenbang Stages

a) Organizing Musrenbang, consisting of activities:

i. Establishment of Musrenbang (TPM) organizing team;

ii. Formation of Village Musrenbang Guide Team by TPM (2-3 people);

iii. The technical preparation for implementing the Village Musrenbang, namely:

- Arranging the village Musrenbang schedule and agenda;

- Announcement of village Musrenbang activities and distribution of invitations to participants and resource persons (at least 7 days before D-day);

- Coordinate logistics preparation (place, consumption, tools and materials).

15 Rianingsih Djohani, Panduan Penyelenggaraan Musyawarah Perencanaan Pembangunan Desa, Bandung, Perpustakaan Nasional Katalog dalam Terbitan (KDT). 2008. p. 6 
b) Participatory village assessment, consisting of activities

i. Study the conditions, problems and potential of the village (per hamlet/RW and/or per sector/development issue) With the community members;

ii. Village data/information compilation from the results of the study by the guiding team.

c) Preparation of the initial draft RKP Desa, consisting of activities:

i. A review of the Village RPJM document and the results of the TPM and Tiim Guide study design,

ii. Review document / data / information on program policies and regional budgets by the TPM and the Guidance Team

iii. Preparation of the draft Initial Village RKP draft with reference to this study by the TPM and the Guidance Team

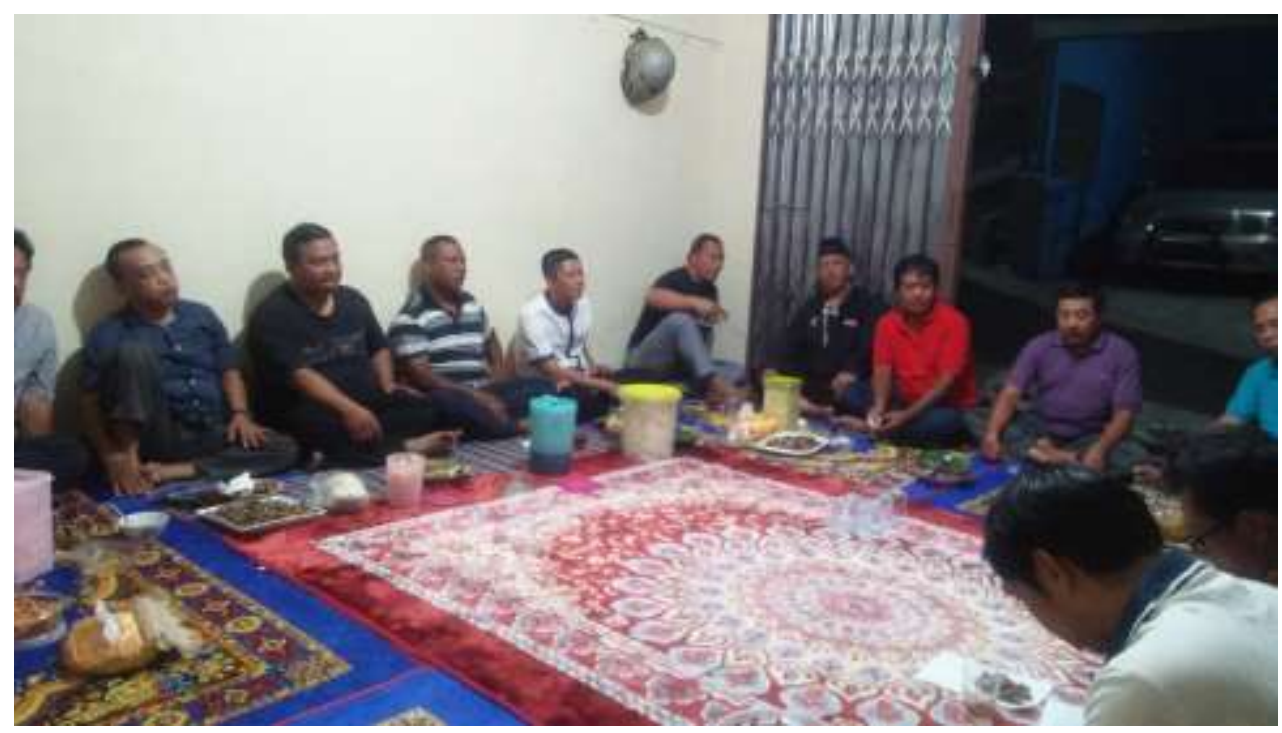

Figure 2. Deliberation of Kalikayen Hamlet, Kalikayen Village

Source: Authors' personal document dated July 30, 2019

2. Stages of the implementation of the village Musrenbang

a) Opening, the event is guided by the presenter with activities as follows:

i. Opening remarks and delivery of the Village Musrenbang agenda

ii. Report from the head of the Musrenbang committee (Chair of TPM);

iii. Message from the village head and official opening;

iv. Prayer Together.

b) Presentation and discussion with resource persons (panel discussion) as input for deliberations: 
i. Presentation by community representatives on the description of village problems according to the results of the study, which were divided according to the affairs / fields of village development;

ii. The village head's explanation of (1) the results of the Village RKP evaluation that has been running; (2) program priority framework according to the Village RPJM; (3) information on the estimated $\mathrm{ADD}$ and other budget sources for the year being planned;

iii. Subdistrict exposure, UUPTD / SKPD kecamatan regarding policies and priorities of regional programs in the subdistrict region;

iv. Responses / discussion with community members.

c) Presentation of draft Initial Village RKP Draft by TPM (usually village secretary) and responses or checking (verification) by participants

d) Agreement on priority activities and budget per sector / issue

e) Deliberation on the determination of the Village Delegation Team

f) Closing is the signing of the minutes of the Musrenbang and the closing remarks by the Chairperson of the TPM / guide.

3. Post-Musrenbang Village Stages

a) Working meetings of the formulating team of the village Musrenbang results: (1) issuance of the Kades SK for the village delegation team; (2) compilation of priority list of village problems to be submitted in the subdistrict Musrenbang; (3) preparation of Village RKP to become Head Village Decree (based on SEB and Permendagri No.66 / 2007) or Head Village regulation (based on PP No.72 / 2005)

b) Provision of the Village Delegation Team by the TPM (including the Guidance Team) so that: (1) mastering data / information and explanations about the proposals that the delegation team will bring to the Musrenbang in the sub-district, and (3) strengthening other capabilities (insight, communication techniques, presentations)

c) Compilation of the Village Budget (APBDes) with reference to the Village Development Work Plan (RKP Desa) document.

Village Deliberation is the highest forum in the village that functions to make decisions on strategic matters. Placing Village Deliberation as part of the democratization framework is intended to prioritize Village Deliberation which is the main mechanism for Village decision making. As such, special attention to Village Deliberation is an integral part of the 
Village democratization framework. The Village Law defines the Village Deliberation as follows: Village Deliberation or what is referred to by other names is a deliberation between the Village Council, the Village Government, and elements of the community organized by the Village Council to agree on strategic matters. ${ }^{16}$

\section{Community Enthusiasm}

The situation in Kalikayen Village requires the village government to fight harder so that the implementation of MUSRENBANG Desa is not just a formality, but also the spearhead of development. This needs to approach the community about the general knowledge of the Village MUSRENBANG, the stages, the role of the community, as well as the procedures for compiling proposed activities for the Village RKP and the Village RPJM. The people of Kalikayen Village consider that the development intended in the MUSRENBANG Desa is only development related to infrastructure. Whereas what is stated in the Village Law is broader, including covering village development, organizing government, empowering village communities and fostering village community institutions. ${ }^{17}$

We facilitate the Kalikayen Village community with a brief article about MUSRENBANG Desa so that it can be conveyed to RW/RT and the wider community. The enthusiasm of the community should be supported by the regional government so that the community's enthusiasm in developing the area is encompassed through the aspirations put forward through the Hamlet Musrenbang and the Village Musrenbang.

\section{Lack of Local Government Assistance in the Implemen-tation of Musrenbang}

The Village Government in carrying out its dutys is under the control of the Regency / City Regional Government, one of which is applied to the correction and evaluation of the raVillage Regulations formed by the Village. However, if you see Village Council conditions that lack knowledge about the functions and procedures to carry out their functions, according to the author it is still the responsibility of the government to foster Village Council so that in the future it can carry out its responsibilities properly and in accordance with the aspirations of the community, especially in Kalikayen Village.

16 Amanulloh, Naeni. Buku 3: Demokratisasi Desa. Jakarta, Kementerian Desa, Pembangunan Daerah Tertinggal, dan Transmigrasi Republik Indonesia: 2015, p.36

17 Interview with Mashudi, S.Ag. Head of Government Affairs on August 25, 2019 at 19.38 WIB 
The implementation process in Kalikayen Village is far from perfect, because the Village Musrenbang that should have been able to take place a maximum of 3 months after the election of a new village head, until now in August 2019 there has not yet been formed a drafting team for the Village RPJM and the Village RKP. Furthermore, we were accompanied by the filling out of plans for proposed activities and priority issues in the village so that later they could become material for the hamlet head in leading / guiding the Development Planning Consultation at the hamlet level.

\section{Conclusion}

The method of fostering the Village Council Post Village Head Election is carried out through a number of ways including education and training in the formation of Village regulations, assistance in the formation of Village Unity, and assistance in the Village Musrenbang. The above method is needed considering the lack of knowledge of the Village Council for village development planning and other fungal dutys. The community has not received assistance or guidance from the regional government, especially for members of the Kalikayen Village Council. The government is expected to give more attention to the village so that the village can exercise its authority to the fullest.

\section{E. Acknowledgments}

Our gratitude goes to all those who have helped us during the Community Service Program in Kalikayen Village. This article is dedicated to deepen the science of law, especially in the field of Constitutional Law and as an outcome of the Community Service Program Partnership Drafting Regulations for Phase II of 2019.

\section{F. Declaration of Conflicting Interests}

The authors state that there is no potential conflict of interest in the research, authorship, and / or publication / publication of this article. 


\section{G. Funding}

Program of the community services and research funded by Authors it self as well as publication. Authors declare that there is no sponsorhip or any other parties funded the program.

\section{H. References}

Amanulloh, N. (2015). Buku 3: Demokratisasi Desa. Jakarta : Kementerian Desa, Pembangunan Daerah Tertinggal, dan Transmigrasi Republik Indonesia.

Aziz, N.L.Y. (2016). Otonomi Desa dan Efektivitas Dana Desa. Jurnal Penelitian Politik. 13(2):

Djohani, R. (2008). Panduan Penyelenggaraan Musyawarah Perencanaan Pembangunan Desa. Bandung: Perpustakaan Nasional Katalog dalam Terbitan (KDT).

Djogo, T. (2003). Kelembagaan dan Kebijakan Dalam Pengembangan Agroforesti. Word Agroforestry Centre (ICRAF) Southeast Asia.

Ihsan, M.M. (2015). Ketahanan Masyarakat Desa. Kementrian Desa. Jakarta: Pembangunan Daerah Teringgal, dan Transmigrasi Republik Indonesia.

Maddick, H., \& Nurcholis, H. (2007). Teori dan Praktik Pemerintahan dan Otonomi Daerah. Grasindo: Jakarta.

Marjoko, S.I., \& Hawari, H. (2013). Pemerintah Desa yang Baik. Medan: Bitra Indonesia, The Activator for Rural Progress.

Miskawati \& Tahir, H. (2014). Peran Badan Permusyawaratan Desa (VILLAGE COUNCIL) Pembangunan Desa (Studi di Desa Tolajuk Kecamatan Latimojong Kabupaten Luwu). Thesis. Makassar: Universitas Negeri Makassar.

Ndraha, T. (2002). Pembangunan Masyarakat. Jakarta: Rineka Cipta.

Peraturan Pemerintah Nomor 43 Tahun 2014 tentang Peraturan Pelaksana Undang-Undang Nomor 6 tahun 2014 tentang Desa

Peraturan Menteri Dalam Negeri Nomor 114 Tahun 2014 tentang Pedoman Pembangunan Desa

Saparin, S. (2015). Luas Bidang Kegiatan Pemerintahan, Tata Pemerintahan dan Administrasi Pemerintahan Desa. Jakarta: Ghalia Indonesia. 
Silahudin, M. (2015). Kewenangan desa dan Regulasi Desa. Jakarta: Kementerian Desa, Pembangunan Daerah Tertinggal dan Transmigrasi Republik Indonesia.

Tim Kementerian Dalam Negeri \& Australian Government. Buku Panduan VILLAGE COUNCIL 2018. Jakarta: KOMPAK Kemitraan Pemerintah Australia dan Indonesia.

Undang-Undang Republik Indonesia Nomor 6 Tahun 2014 tentang Desa.

Waluyo, B. (1996). Penelitian Hukum dalam Praktek. Jakarta: Sinar Grafika.

Widjaja, HAW. (2008). Otonomi Desa: Merupakan Otonomi yang Asli, Bulat dan Utuh. Jakarta: PT Raja Grafindo Persada. 


\section{QUOTE}

\section{Service without humility is selfishness and egotism}

Mahatma Gandhi

Copyrights (C) 2019 by Auhtor(s). This work is licensed under a Creative Commons Attribution-NonCommercial-ShareAlike 4.0 International License. All writings published in this journal are personal views of the authors and do not represent the views of this journal and the author's affiliated institutions. 